FOLIA POMERANAE UNIVERSITATIS TECHNOLOGIAE STETINENSIS

Folia Pomer. Univ. Technol. Stetin., Oeconomica 2018, 344(91)2, 49-60

\title{
NAUCZANIE RACHUNKOWOŚCI NA POZIOMIE SZKOLNICTWA WYŻSZEGO A OCZEKIWANIA STUDENTÓW I PRACODAWCÓW W ZAKRESIE KOMPETENCJI I UMIEJĘTNOŚCI DOTYCZĄCYCH RACHUNKOWOŚCI
}

\author{
ACCOUNTING LEARNING AT THE LEVEL OF HIGHER EDUCATION \\ AND STUDENTS 'AND EMPLOYERS' EXPECTATIONS IN THE AREA \\ OF COMPETENCE AND SKILLS ABOUT THE SCOPE OF ACCOUNTING
}

\author{
Katedra Ekonomii i Rachunkowości, Zachodniopomorski Uniwersytet Technologiczny w Szczecinie \\ ul. Żołnierska 47, 71-210 Szczecin, imajchrzak@zut.edu.pl \\ *studentka studiów stacjonarnych drugiego stopnia na kierunku ekonomia, Zachodniopomorski \\ Uniwersytet Technologiczny w Szczecinie, ul. Żołnierska 47, 71-210 Szczecin
}

\begin{abstract}
Summary. The aim of the article is to determine the expectations of students and employers of the West Pomeranian Province regarding competences and skills in the field of accounting in the light of the educational offer in this area available at Szczecin state universities. The elaboration of the article was preceded by literature studies and surveys conducted among students of economic faculties of two Szczecin universities and employers of the West Pomeranian Province. In addition, the programs of education of the surveyed entities in the field of accounting were analyzed. The main method used in the article is the analysis of sources and the method of deduction and induction. The conducted research allowed to state unequivocally that the educational offer of Szczecin's economic faculties, though it is constantly changing and adapting to the changing needs of students and the labor market, still does not meet the expectations of both sides. The respondents indicate that they acquire too much theoretical knowledge in the process of education and too little practical skills. They believe that these relationships should be change.
\end{abstract}

Słowa kluczowe: rachunkowość, kompetencje, umiejętności.

Key words: accounting competences, skills.

\section{WSTĘP}

Nauczanie rachunkowości w XXI wieku jest zadaniem bardzo trudnym, ponieważ powinno uwzględniać dynamicznie rosnące oczekiwania rynku pracy. Współczesny księgowy bowiem to już nie tylko osoba, która rejestruje zdarzenia gospodarcze, ale przede wszystkim doradca (Szydełko 2011). Potrafi ona na podstawie informacji pochodzących $z$ systemu rachunkowości podejmować racjonalne decyzje gospodarcze. Ponadto zmieniające się nieustannie przepisy prawa powodują, że wykonywanie zawodu księgowego wymaga stałego pogłębiania oraz uzupełniania i uaktualniania zdobytej wiedzy. Tym samym studenci decydujący się na wybór kierunku bądź specjalności z zakresu rachunkowości mają określone wyobrażenia i oczekiwania dotyczące możliwości zdobycia wiedzy i umiejętności umożliwiających im właściwe przygotowanie się do wykonywania zawodu księgowego. W związku z tym autorki niniejszego artykułu podjęły próbę określenia oczekiwań studentów 
i pracodawców z województwa zachodniopomorskiego wobec kompetencji i umiejętności z zakresu rachunkowości w odniesieniu do oferty edukacyjnej dostępnej na szczecińskich uczelniach państwowych. Celem artykułu jest zatem przedstawienie opinii respondentów na ten temat oraz wskazanie kierunków zmian niezbędnych w nauczaniu rachunkowości dla zapewnienia optymalnego przygotowania absolwentów wyższych szkół ekonomicznych do wymagań rynku pracy.

\section{MATERIAŁ I METODY}

Opracowanie artykułu poprzedziły studia literaturowe w zakresie nauczania rachunkowości na uczelniach wyższych, obejmujące między innymi zadania i funkcje rachunkowości i ich ewolucję (Micherda 2011), standardy kształcenia w zakresie rachunkowości na studiach ekonomicznych (Międzynarodowe Standardy Edukacyjne 2016) oraz czynniki wpływające na proces nauczania rachunkowości (Szczypa 2015). Ponadto na potrzeby określenia oferty edukacyjnej w zakresie rachunkowości przeprowadzono analizę porównawczą treści kształcenia w tym zakresie na szczecińskich uczelniach państwowych kształcących przyszłych księgowych. Oferta ta została porównana z oczekiwaniami studentów tych uczelni i pracodawców województwa zachodniopomorskiego.

Poznanie oczekiwań studentów i pracodawców województwa zachodniopomorskiego umożliwiły badania ankietowe. Opracowano dwie ankiety skierowane do studentów III roku wydziałów ekonomicznych szczecińskich uczelni publicznych studiujących na kierunku lub specjalności finanse i rachunkowość oraz do pracodawców województwa zachodniopomorskiego. W celu poznania opinii pracodawców na temat przygotowania absolwentów szkół wyższych do wykonywania zawodu księgowego ankietę badawczą skierowano bezpośrednio do właścicieli biur rachunkowych prowadzących działalność na terenie objętym badaniem.

Badania wśród studentów i pracodawców przeprowadzono w okresie od maja do listopada 2017 roku. Kwestionariusz ankiety został udostępniony studentom drogą elektroniczną oraz w wersji papierowej, natomiast ankieta dla pracodawców została rozesłana drogą elektroniczną do 40 biur rachunkowych z województwa zachodniopomorskiego wyłonionych za pomocą wyszukiwarki internetowej.

Opracowany kwestionariusz ankiety dla studentów zawierał 21 pytań. W ankiecie znajdowały się pytania jedno- i wielokrotnego wyboru, pytania dotyczące oceny według skali oraz pytania, w przypadku których student mógł sam wskazać odpowiedź. Pytania dotyczyły, między innymi, oceny programu nauczania w zakresie rachunkowości na badanych uczelniach, tj. na Zachodniopomorskim Uniwersytecie Technologicznym w Szczecinie i na Uniwersytecie Szczecińskim, zdobytych kompetencji i umiejętności w zakresie rachunkowości podczas zajęć oraz ich przydatności w praktyce. Ponadto respondenci mieli możliwość wskazania obszarów wymagających zmian w programie nauczania przedmiotów z zakresu rachunkowości.

Ankieta dla pracodawców zawierała 9 pytań - pytania jedno- i wielokrotnego wyboru oraz pytanie umożliwiające dokonanie oceny według określonej skali. W większości były to pytania dotyczące oceny przygotowania absolwentów wyższych szkół ekonomicznych do wykonywania pracy w zawodzie księgowego. Pracodawcy odpowiadając na pytania, mogli również wskazać pożądane cechy i zdolności, które powinny posiadać osoby starające się 
o pracę w biurze rachunkowym. Ponadto pracodawcy mieli możliwość oceny programów nauczania rachunkowości na analizowanych uczelniach szczecińskich.

W badaniu studentów uczestniczyło łącznie 76 respondentów, w tym 31 studentów Wydziału Ekonomicznego Zachodniopomorskiego Uniwersytetu Technologicznego w Szczecinie (ZUT), 29 studentów Wydziału Nauk Ekonomicznych i Zarządzania Uniwersytetu Szczecińskiego (WNEiZ) i 16 studentów Wydziału Zarządzania i Ekonomiki Usług Uniwersytetu Szczecińskiego (WZiEU). Zdecydowaną większość respondentów wśród studentów trzech wydziałów ekonomicznych publicznych uczelni szczecińskich stanowiły kobiety (74\%).

Z uwagi na małą próbę badawczą oraz zbliżone programy kształcenia w zakresie rachunkowości na wszystkich badanych wydziałach w dalszej części badań nie dokonano różnicowania respondentów pod względem miejsca studiowania. Zdaniem autorek artykułu takie podejście nie wpływa na zafałszowanie wyników, a jedynie przyczynia się do zwiększenia ich efektywności i przejrzystości formułowanych wniosków.

\section{ANALIZA PORÓWNAWCZA TREŚCI KSZTAŁCENIA W ZAKRESIE RACHUNKOWOŚCI W BADANYCH JEDNOSTKACH}

Zmiany zachodzące w otoczeniu uczelni wyższych powodują, że każda jednostka dąży do przygotowania oferty edukacyjnej w sposób zorientowany zarówno na studenta, który poszukuje wiedzy, jak i na pracodawcę, który poszukuje pracowników o odpowiednich kwalifikacjach i umiejętnościach. Dlatego programy kształcenia są uwarunkowane wieloma czynnikami - zarówno wewnętrznymi, jak i zewnętrznymi (tab. 1).

Tabela 1. Czynniki wpływające na proces nauczania rachunkowości

\begin{tabular}{|c|c|c|}
\hline Charakter & Rodzaj & Charakterystyka \\
\hline \multirow{5}{*}{ 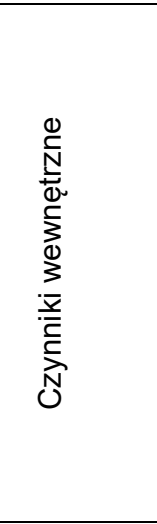 } & $\begin{array}{l}\text { wiedza } \\
\text { i umiejętności } \\
\text { nauczyciela }\end{array}$ & $\begin{array}{l}\text { Są to najważniejsze czynniki sukcesu nauczyciela. Bez wykształcenia } \\
\text { i bogatej wiedzy na temat rachunkowości, popartej praktyką i umie- } \\
\text { jętnościami, trudno mówić o skutecznym nauczaniu tego przedmiotu }\end{array}$ \\
\hline & $\begin{array}{l}\text { wykształcenie } \\
\text { pedagogiczne }\end{array}$ & $\begin{array}{l}\text { Wykształcenie pedagogiczne wyposaża nauczyciela w przydatną wiedzę na } \\
\text { temat, między innymi, pracy ze studentami, prawidłowego układania pytań do } \\
\text { testów, zadań, kształtowania prawidłowych postaw społecznych studentów }\end{array}$ \\
\hline & $\begin{array}{l}\text { predyspozycje } \\
\text { osobiste }\end{array}$ & $\begin{array}{l}\text { Kultura osobista nauczyciela akademickiego, jego charyzma mają wpływ na } \\
\text { przekaz wiedzy i skuteczność procesu nauczania }\end{array}$ \\
\hline & $\begin{array}{l}\text { rodzaj uczelni } \\
\text { i profil } \\
\text { kształcenia }\end{array}$ & $\begin{array}{l}\text { Na kształtowanie procesu nauczania rachunkowości istotny wpływ ma: } \\
\text { - forma własności uczelni (uczelnia publiczna czy niepubliczna) } \\
\text { - rodzaj, uniwersytet (politechnika czy wyższa szkoła zawodowa) } \\
\text { - profil kształcenia (ogólnoakademicki czy praktyczny) }\end{array}$ \\
\hline & styl zarządzania & $\begin{array}{l}\text { Misja uczelni i sposób jej realizacji narzucają określone priorytety oddziału- } \\
\text { jące także na proces nauczania }\end{array}$ \\
\hline \multirow{5}{*}{ 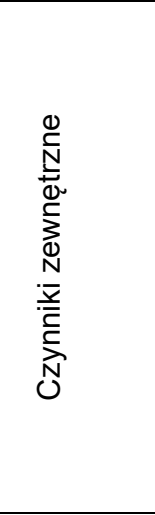 } & przepisy prawa & $\begin{array}{l}\text { Ustawy i rozporządzenia regulują zasady pracy uczelni; dotyczą między } \\
\text { innymi liczby godzin dydaktycznych, nauczycieli akademickich }\end{array}$ \\
\hline & $\begin{array}{l}\text { rynek } \\
\text { edukacyjny }\end{array}$ & $\begin{array}{l}\text { Konkurencja wpływa na ofertę edukacyjną uczelni wyższych. W związku } \\
\text { z tym są tworzone i otwierane nowe specjalności, wykorzystywane nowe } \\
\text { techniki i formy kształcenia, organizowane staże zawodowe, studia pody- } \\
\text { plomowe itp. }\end{array}$ \\
\hline & rynek pracy & $\begin{array}{l}\text { Oczekiwania pracodawców co do umiejętności praktycznych i teoretycznych } \\
\text { absolwentów uczelni wyższych z zakresu rachunkowości }\end{array}$ \\
\hline & $\begin{array}{l}\text { zmiany } \\
\text { demograficzne } \\
\text { i społeczne }\end{array}$ & $\begin{array}{l}\text { Niż demograficzny i emigracja młodzieży powodują coraz mniejsze } \\
\text { zainteresowanie studiami ekonomicznymi. Istotne znaczenie mają również } \\
\text { wzajemne relacje społeczne, w tym wzrost rangi zachowań etycznych }\end{array}$ \\
\hline & $\begin{array}{l}\text { styl zarządzania } \\
\text { jednostkach } \\
\text { gospodarczych }\end{array}$ & $\begin{array}{l}\text { Zarządzanie oparte wyłącznie na relacjach biznesowych, czego wynikiem są } \\
\text { efekty ważniejsze niż relacje międzyludzkie. Zarządzanie oparte na wza- } \\
\text { jemnym szacunku i podkreślaniu etyki w biznesie }\end{array}$ \\
\hline
\end{tabular}

Źródło: opracowano na podstawie: Szczypa (2015). 
Tabela 2. Analiza porównawcza programów kształcenia w badanych jednostkach

\begin{tabular}{|c|c|c|c|}
\hline \multirow{2}{*}{ Wyszczególnienie } & \multirow{2}{*}{$\begin{array}{c}\text { Zachodniopomorski } \\
\text { Uniwersytet Technologiczny } \\
\text { w Szczecinie }\end{array}$} & \multicolumn{2}{|c|}{ Uniwersytet Szczeciński } \\
\hline & & WNEiZ & WZiEU \\
\hline $\begin{array}{l}\text { Przedmioty } \\
\text { ogólne }\end{array}$ & 1. Rachunkowość & 1. Podstawy rachunkowości & 1. Podstawy rachunkowości \\
\hline $\begin{array}{l}\text { Przedmioty } \\
\text { kierunkowe }\end{array}$ & $\begin{array}{l}\text { 1. Rachunkowość } \\
\text { finansowa } \\
\text { przedsiębiorstw }\end{array}$ & $\begin{array}{l}\text { 1. Rachunkowość } \\
\text { finansowa } \\
\text { 2. Rachunkowość małych } \\
\text { firm } \\
\text { 3. Sprawozdawczość } \\
\text { finansowa } \\
\text { 4. Podstawy rachunku } \\
\text { kosztów } \\
\text { 5. Podstawy rachunkowości } \\
\text { zarządczej }\end{array}$ & $\begin{array}{l}\text { 1. Rachunkowość } \\
\text { finansowa } \\
\text { 2. Kontrola finansowo- } \\
\text {-księgowa }\end{array}$ \\
\hline $\begin{array}{l}\text { Przedmioty } \\
\text { specjalnościowe }\end{array}$ & $\begin{array}{l}\text { 1. Organizacja } \\
\text { rachunkowości } \\
\text { 2. Sprawozdawczość } \\
\text { finansowa } \\
\text { 3. Rachunek kosztów } \\
\text { i wyników } \\
\text { 4. Rachunkowość } \\
\text { informatyczna } \\
\text { 5. Rachunkowość } \\
\text { jednostek sektora } \\
\text { finansów publicznych }\end{array}$ & $\begin{array}{l}\text { 1. Podstawy auditingu (1) } \\
\text { 2. Rachunkowość instytucji } \\
\text { finansowych (1) } \\
\text { 3. Rachunkowość } \\
\text { budżetowa (1) } \\
\text { 4. Organizacja } \\
\text { rachunkowości } \\
\text { przedsiębiorstw (1, 2) } \\
\text { 5. Rozliczenia } \\
\text { publicznoprawne } \\
\text { przedsiębiorstw (1, 2) } \\
\text { 6. Systemy finansowo- } \\
\text {-księgowe (1, 2) } \\
\text { 7. Zastosowanie internetu } \\
\text { w rachunkowości (1) } \\
\text { 8. Rachunkowość } \\
\text { instrumentów } \\
\text { finansowych (1) } \\
\text { 9. Rachunkowość } \\
\text { międzynarodowa (1) } \\
\text { 10. Międzynarodowe } \\
\text { regulacje } \\
\text { rachunkowości (2) } \\
\text { 11. Interpretacja } \\
\text { sprawozdań } \\
\text { finansowych (2) } \\
\text { 12. Rachunkowość } \\
\text { finansowa (case } \\
\text { study) (3) } \\
\text { 13. Narzędzia optymalizacji } \\
\text { procesów w } \\
\text { rachunkowości (3) } \\
\text { 14. Organizacja } \\
\text { rachunkowości i } \\
\text { kontrola wewnętrzna (3) } \\
\text { 15. Wprowadzenie do } \\
\text { rachunkowości } \\
\text { międzynarodowej (3) }\end{array}$ & $\begin{array}{l}\text { 1. Systemy informatyczne } \\
\text { w rachunkowości } \\
\text { finansowej }(4,6) \\
\text { 2. Wycena bilansowa }(4,6) \\
\text { 3. Rachunkowość } \\
\text { społecznej } \\
\text { odpowiedzialności (4) } \\
\text { 4. Rachunkowość małych } \\
\text { firm }(4,6) \\
\text { 5. Komputerowa ewidencja } \\
\text { księgowa (5) } \\
\text { 6. Rachunkowość kadr } \\
\text { i płac (5) } \\
\text { 7. Organizacja } \\
\text { rachunkowości (5) } \\
\text { 8. Kalkulacja i rozliczanie } \\
\text { kosztów (5) } \\
\text { 9. Ewidencje podatkowe } \\
\text { w mikroprzedsiębior- } \\
\text { stwach i małych } \\
\text { przedsiębiorstwach (5) } \\
\text { 10. Wycena w systemie } \\
\text { rachunkowości (5) }\end{array}$ \\
\hline $\begin{array}{l}\text { Przedmioty } \\
\text { obieralne }\end{array}$ & $\begin{array}{l}\text { 1. Elementy } \\
\text { rachunkowości } \\
\text { zarządczej }\end{array}$ & - & - \\
\hline
\end{tabular}

Objaśnienia numerów podanych w nawiasach: 1 - rachunkowość i sprawozdawczość finansowa, 2 rachunkowość i finanse przedsiębiorstw, 3 - rachunkowość i finanse usług biznesowych, 4 - rachunkowość i controlling, 5 - rachunkowość przedsiębiorstw, 6 - rachunkowość i prawo w biznesie.

Źródło: opracowano na podstawie programów kształcenia badanych jednostek. 
Czynniki wskazane w tab. 1 nie stanowią zamkniętego katalogu przyczyn wpływających na proces nauczania rachunkowości na poziomie szkolnictwa wyższego, są jednak kluczowe, ponieważ $\mathrm{w}$ istotny sposób oddziałują na pracę nauczyciela akademickiego i studenta.

Ze względu na różnorodność czynników wpływających na proces nauczania rachunkowości na uczelniach wyższych analizie porównawczej poddano treści kształcenia w zakresie rachunkowości na trzech szczecińskich wydziałach przygotowujących, między innymi, do wykonywania zawodu księgowego, tj. na Wydziale Ekonomicznym Zachodniopomorskiego Uniwersytetu Technologicznego w Szczecinie (ZUT) oraz na dwóch wydziałach ekonomicznych Uniwersytetu Szczecińskiego.

$\mathrm{Na}$ Wydziale Ekonomicznym ZUT w Szczecinie studia w zakresie rachunkowości odbywają się na kierunku ekonomia na specjalności rachunkowość i finanse w jednostkach gospodarczych. Natomiast na Wydziale Nauk Ekonomicznych i Zarządzania (WNEiZ) Uniwersytetu Szczecińskiego i na drugim z wydziałów tej uczelni, tj. na Wydziale Zarządzania i Ekonomiki Usług (WZiEU) studenci chcący studiować rachunkowość wybierają kierunek finanse i rachunkowość. W ramach tego kierunku studenci WNEiZ mogą zdobywać wiedzę z zakresu rachunkowości w ramach takich specjalności, jak rachunkowość i sprawozdawczość finansowa, rachunkowość i finanse przedsiębiorstw, rachunkowość i finanse usług biznesowych. Natomiast na WZiEU studenci mogą wybrać specjalność rachunkowość i controlling, rachunkowość i prawo w biznesie oraz rachunkowość przedsiębiorstw. Analizę porównawczą programów kształcenia w zakresie rachunkowości, realizowanych w badanych jednostkach, przedstawia tab. 2.

Jak wynika z przeprowadzonej analizy porównawczej programów kształcenia w zakresie rachunkowości, najbogatszą ofertę ma Wydział Nauk Ekonomicznych i Zarządzania Uniwersytetu Szczecińskiego. Ma on również zdecydowanie najwięcej godzin nauczania rachunkowości w ramach realizowanych specjalności. Dlatego też wydział ten ma najwięcej słuchaczy pragnących znaleźć zatrudnienie w szeroko rozumianej księgowości. Należy jednak podkreślić, iż każdy z wydziałów ekonomicznych szczecińskich uczelni publicznych stara się dostosować programy kształcenia do zmieniających się oczekiwań rynku pracy. Tym samym nie można stwierdzić, który wydział lepiej wyposaża swoich absolwentów w wiedzę i umiejętności w zakresie rachunkowości.

\section{OCZEKIWANIA STUDENTÓW W ZAKRESIE NAUCZANIA RACHUNKOWOŚCI}

Badanie oczekiwań studentów w zakresie nauczania rachunkowości rozpoczęto od określenia rodzaju ukończonej szkoły średniej. Przyjęto bowiem, że wcześniej zdobyta wiedza i umiejętności mogą być wyznacznikiem podjęcia dalszej edukacji w zakresie rachunkowości.

Wyniki przeprowadzonych badan wykazały, że największy odsetek stanowili absolwenci liceów ogólnokształcących (55\%) oraz techników ekonomicznych (24\%). Strukturę respondentów ze względu na ukończoną szkołę średnia przedstawia ryc. 1. 


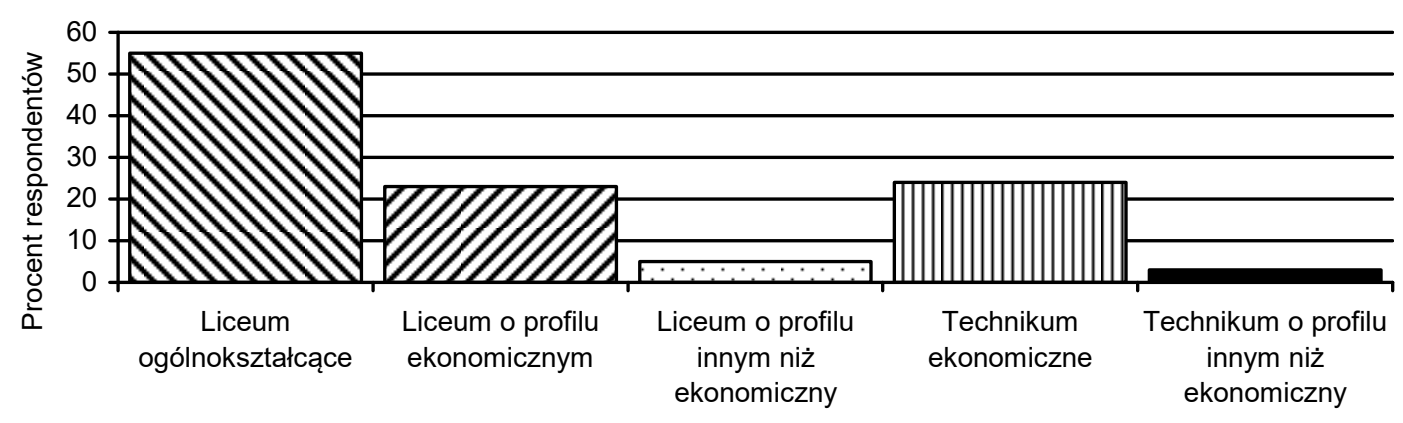

Ryc. 1. Struktura respondentów ze względu na ukończoną szkołę średnią Źródło: wyniki badań ankietowych.

Wybór kierunku studiów, zarówno przez studentów Zachodniopomorskiego Uniwersytetu Technologicznego w Szczecinie, jak i Uniwersytetu Szczecińskiego, wynikał z perspektywy pozyskania dobrej pracy $(61 \%)$ oraz z wpływu rodziny $(24 \%)$. Można przypuszczać, iż studenci wybierający specjalność związaną z rachunkowością pod wpływem najbliższych na co dzień obcują z osobami pracującymi w tym zawodzie. Ponadto respondenci mieli możliwość samodzielnego wskazania powodu dokonanego wyboru studiów, a następnie specjalności. Stwierdzali najczęściej, że o ich wyborze decydowały predyspozycje do wykonywania zawodu księgowego lub że wybór był konsekwencją braku możliwości podjęcia studiów na innych interesujących kierunkach i/ lub specjalnościach. Strukturę studentów ze względu na powód wyboru kierunku/ specjalności studiów związanych z rachunkowością przedstawia ryc. 2.

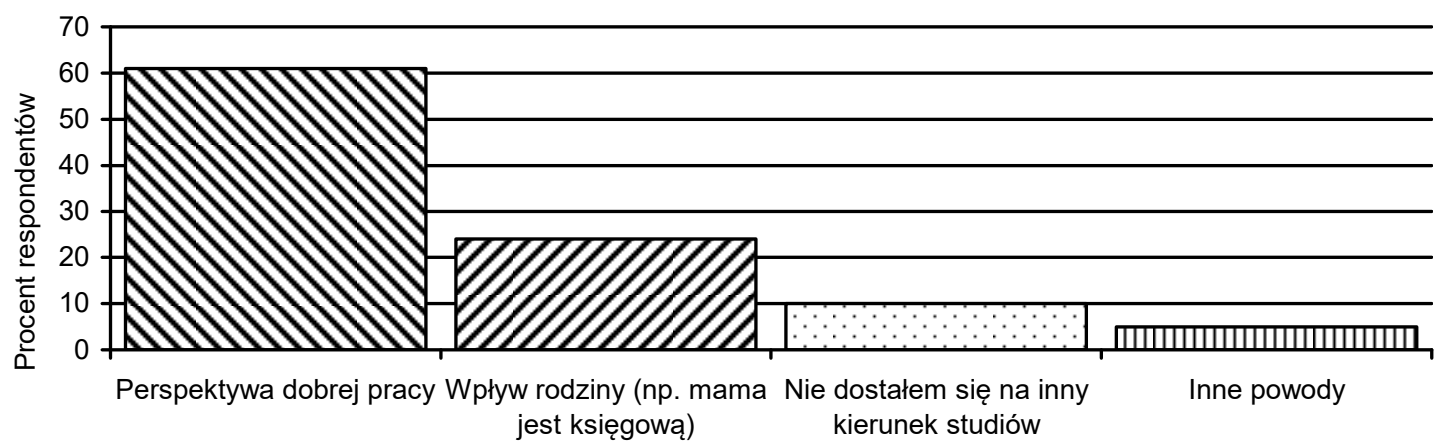

Ryc. 2. Struktura respondentów ze względu na powód wyboru kierunku/ specjalności studiów Żródło: wyniki badań ankietowych.

Przeprowadzone badania wykazały, że respondenci najłatwiej przyswajają wiedzę z zakresu rachunkowości na ćwiczeniach (43\%) oraz na wykładach (24\%). Inne formy prowadzenia zajęć nie stanowią według opinii badanych studentów łatwego źródła pozyskania wiedzy. Zdecydowana większość ankietowanych (87\%) stwierdziła, że to właśnie na ćwiczeniach zdobywa najwięcej wiedzy praktycznej.

Według badanych studentów najefektywniejszą formą prowadzenia ćwiczeń z zakresu rachunkowości jest praca przy komputerze z wykorzystaniem programów księgowych i prowadzenie symulacji działalności gospodarczej. Natomiast rozwiązaywanie zadań odgrywa mniejsze znaczenie, mimo że - jak wykazały przeprowadzone badania - $w$ tej formie są najczęściej prowadzone ćwiczenia (75\%). 
Respondenci pytani byli również o cechy, jakie wypracowali w sobie podczas zajęć z rachunkowości. Badania wykazały, że zajęcia z rachunkowości uczą przede wszystkim zorganiowania i terminowości. Ponadto słuchacze nabywają wiele innych cech - istotnych w przyszłej pracy zawodowej oraz życiu osobistym, takich jak: sumienność, odpowiedzialność, skrupulatność.

W celu oceny przydatności przedmiotów realizowanych na kierunku/ specjalności do kształcenia umiejętności praktycznych i teoretycznych z rachunkowości studenci posługiwali się pięciostopniową skalą, gdzie 1 oznaczało przedmiot najmniej przydatny, natomiast 5 - najbardziej pożądany. Z przeprowadzonych badań wynika, że przedmiotami najbardziej przydatnymi do poznania zasad funkcjonownia rachunkowości są przedmioty, na których można zdobyć podstawową wiedzę z zakresu podstaw rachunkowości, rachunkowości finansowej, sprawozdawczości finansowej czy rachunkowości informatycznej. Według opinii studentów najmniej przydatny w procesie zdobywania umiejętności jest materiał realizowany w ramach przedmiotów dotyczących jednostek sektora fianansów publicznych (ryc. 3). Można przypuszczać, że tak niska ocena tego przedmiotu jest spowodowana brakiem zrozumienia omawianych zagadnień ze względu na zbyt małą liczbę godzin zajęć dydatktycznych bądź niewłaściwy czas ich realizacji w toku studiów.

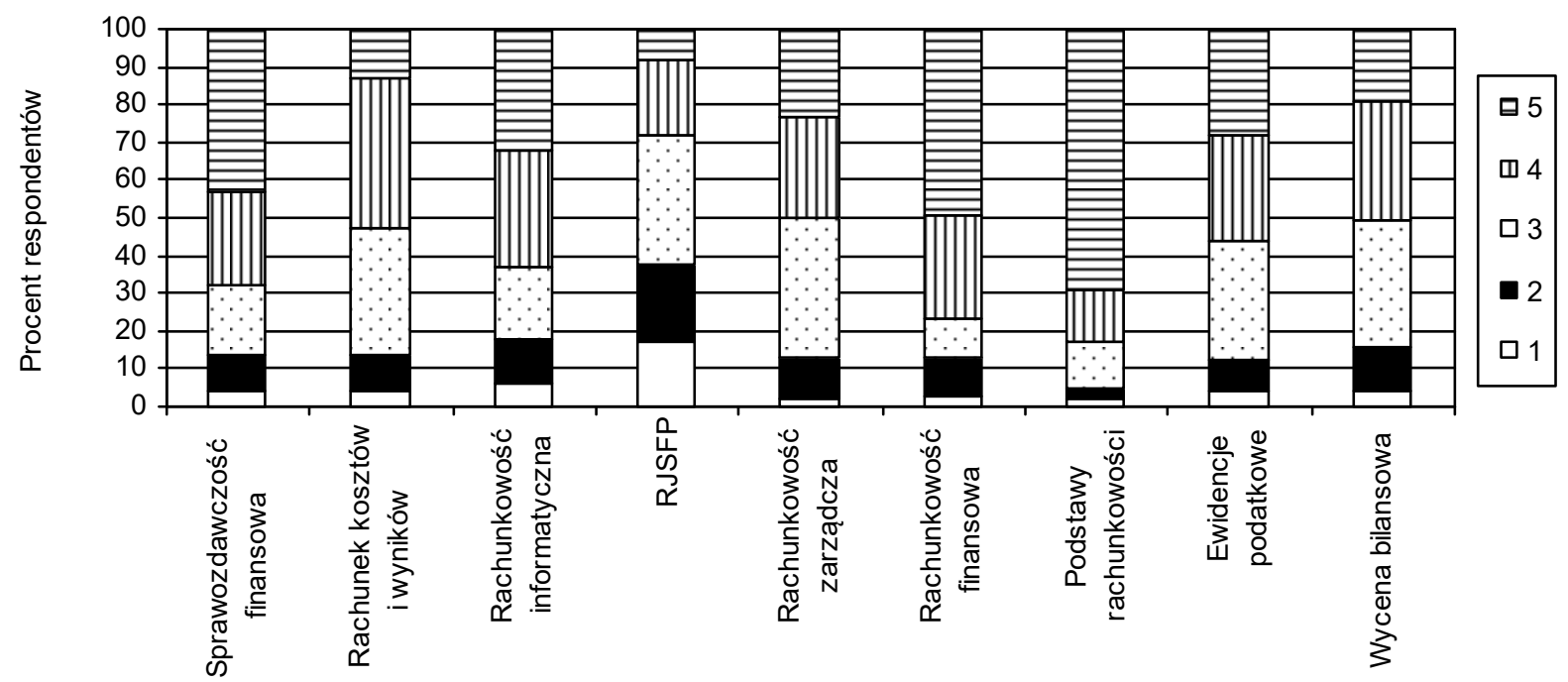

Ryc. 3. Przydatność poszczególnych przedmiotów z rachunkowości w skali 1-5 Źródło: wyniki badań ankietowych.

Z przeprowadzonych badań wynika, że wiedza z zakresu rachunkowości zdobyta na studiach przydała się ponad połowie studentów podczas odbywania praktyk zawodowych/ stażu (62\%). Oni też w większości nie mieli żadnych trudności w wykonywaniu powierzonych im przez pracodawców obowiązków (47\%). Ewentualne trudności wynikały najczęściej z nieznajomości programów księgowych, na których mieli pracować (29\%).

Aż $67 \%$ ankietowanych studentów chciałoby wprowadzić zmiany w programie nauczania w zakresie rachunkowości na swoich uczelniach. Wszyscy zgodnie stwierdzili, że powinno być zdecydowanie więcej zajęć praktycznych, prowadzonych w małych grupach, w szczególności z użyciem programów komputerowych. Zasugerowali również, że liczba godzin 
zajęć z rachunkowości powinien zostać zwiększony kosztem innych zajęć, tj. zajęć niezwiązanych z obranym kierunkiem/ specjalnością.

Z przeprowadzonych badań wynika, że studenci są zainteresowani przedmiotami $z$ zakresu audytu. Przedmioty obejmujące zagadnienia audytu nie są realizowane $w$ badanych jednostkach $w$ ramach studiów pierwszego stopnia. Zapotrzebowanie na tego rodzaju wiedzę może wynikać z faktu, że duża część respondentów wskazała zawód audytora wśród zawodów, które chciałaby wykonywać (ryc. 4).

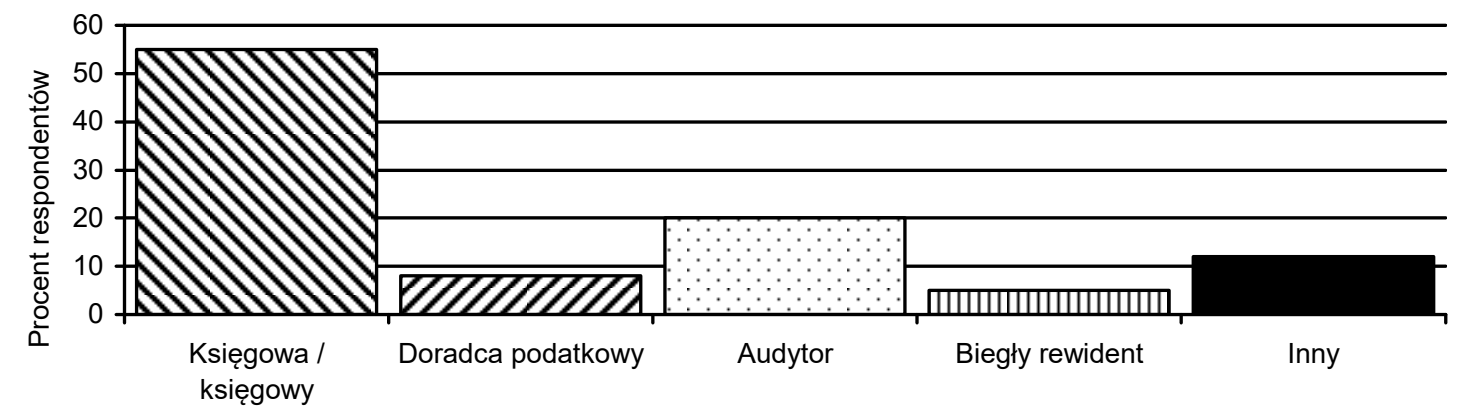

Ryc. 4. Struktura respondentów ze względu na chęć podjęcia pracy w zawodzie wykorzystującym wiedzę i umiejętności z zakresu rachunkowości

Żródło: wyniki badań ankietowych.

Niepokojący jest fakt, że aż $47 \%$ badanych studentów obawia się, że po ukończeniu studiów pierwszego stopnia nie będzie przygotowanych do wykonywania zawodu związanego z podjętym kierunkiem/ specjalnością studiów.

Dla studentów, którzy ukończyli III rok studiów, zajęcia z rachunkowości są na takim samym poziomie trudności, jakiego oczekiwali (63\%); dla 20\% respondentów rachunkowość okazała się trudniejsza.

Wśród studentów kończących studia ekonomicze pierwszego stopnia na kierunkach/ specjalnościach związanych z rachunkowością opinia na temat zawodu księgowego jest zróżnicowana - 45\% badanych uważa, że zawód księgowego jest ciekawy, dla 22\% respondentów ten zawód jest nudny, natomiast dla $8 \%$ - fascynujący.

Na podstawie przeprowadzonych badań można stwierdzić, że większość studentów po ukończeniu III roku studiów pierwszego stopnia nie czuje się właściwie przygotowana do samodzielnej pracy w zawodach związanych z rachunkowością. Według ich opinii posiadają dużo wiedzy teoretycznej, a umiejętności praktyczne są niewielkie. Ponadto zdobytej wiedzy i umiejętności nie potrafią wykorzystać w praktyce. Według respondentów w programach nauczania jest za mało przedmiotów z rachunkowości, a za dużo spoza jej obszarów. Dlatego uważają, że ta struktura powinna ulec zmianie.

\section{OCZEKIWANIA PRACODAWCÓW WOBEC ABSOLWENTÓW WYŻSZYCH SZKÓŁ EKONOMICZNYCH W ZAKRESIE KOMPETENCJI I UMIEJĘTNOŚCI DOTYCZĄCYCH RACHUNKOWOŚCI}

Badania przeprowadzone wśród pracodawców wykazały, że poszukują oni absolwentów wyższych szkół ekonomicznych przygotowanych do wykonywania zawodu księgowego. Wśród badanych pracodawców 83,33\% zatrudniło już w swoich biurach absolwentów uczelni 
ekonomicznych. Respondenci, którzy nie zdecydowali się jeszcze na zatrudnienie w swoim biurze absolwentów uczelni ekonomicznych, to właściciele jednostek małych krótko funkcjonujących na rynku. Ponadto decyzję o niezatrudnianiu absolwentów uzasadniają oni brakiem doświadczenia. Dla tych właścicieli biur rachunkowych cenne są osoby z doświadczeniem, które posiadają określoną wiedzę praktyczną i nie wymagają wprowadzania w pracę księgowego.

Respondenci, którzy zatrudnili w swoim biurze absolwentów wyższych szkół ekonomicznych mogli dokonać oceny ich przygotowania do wykonywania powierzonych im obowiązków. Ocenę przygotowania absolwentów wyższych szkół ekonomicznych do wykonywania zawodu księgowej/go przedstawia ryc. 5. Niestety, uzyskane wyniki badań wskazują w większości $(51 \%)$ na ich przeciętne przygotowanie do wykonywania powierzonych zadań. Po analizie odpowiedzi na inne pytania, można stwierdzić, że ocena to wynika z braku umiejętności praktycznych absolwentów.

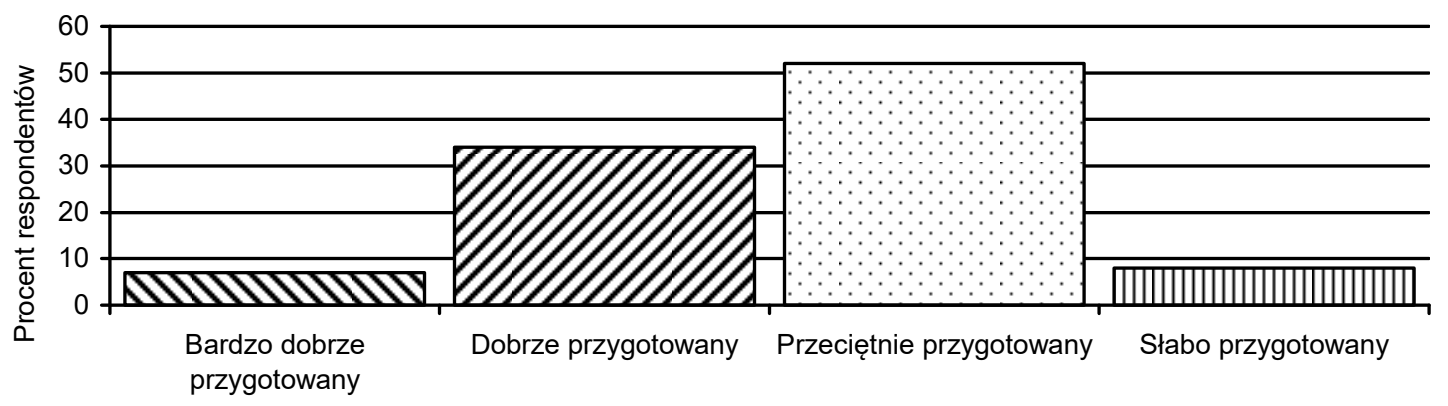

Ryc. 5. Ocena poziomu przygotowania absolwentów studiów ekonomicznych do wykonywania pracy księgowego

Żródło: wyniki badań ankietowych.

Kolejne pytanie, skierowane do pracodawców województwa zachodniopomorskiego, dotyczyło oceny przygotowania absolwentów do pracy w zakresie wskazanych obszarów, tj. pożądanych cech i zdolności kandydata do pracy. Ankietowani dokonywali oceny w pięciostopniowej skali, gdzie 1 oznacza bardzo słabe przygotowanie, natomiast 5 - bardzo dobre. Na to pytanie również odpowiadali tylko ci respondenci, którzy zatrudniają lub zatrudniali w swoim biurze rachunkowym absolwentów wyższych szkół ekonomicznych. Najsłabiej ocenione zostały umiejętności praktyczne absolwentów, najlepiej natomiast rzetelność i sprawność w wykonywaniu poleceń. Wysoko oceniona została także wiedza teoretyczna (ryc. 6).

Przeprowadzone badania wykazały również, że studenci ostatnich lat studiów i absolwenci sami poszukują pracy w biurach rachunkowych. Aż 56,67\% absolwentów samodzielnie poszukuje pracy, a $36,36 \%$ zdobywa ją w wyniku rekrutacji przeprowadzonej na podstawie zapotrzebowania wskazanego w ogłoszeniu.

Ankietowani byli pytani również o czynniki wpływające na podjęcie decyzji o przyjęciu danego kandydata do pracy. Na pytanie to respondenci mogli udzielić wielu odpowiedzi. Było ono skierowane do wszystkich badanych właścicieli biur rachunkowych, tj. również do tych, którzy jeszcze nie zatrudniali w swoim biurze absolwentów wyższych szkół ekonomicznych. Czynniki decydujące o przyjęciu absolwenta do pracy według opinii właścicieli biur rachunkowych przedstawia ryc. 7 . 


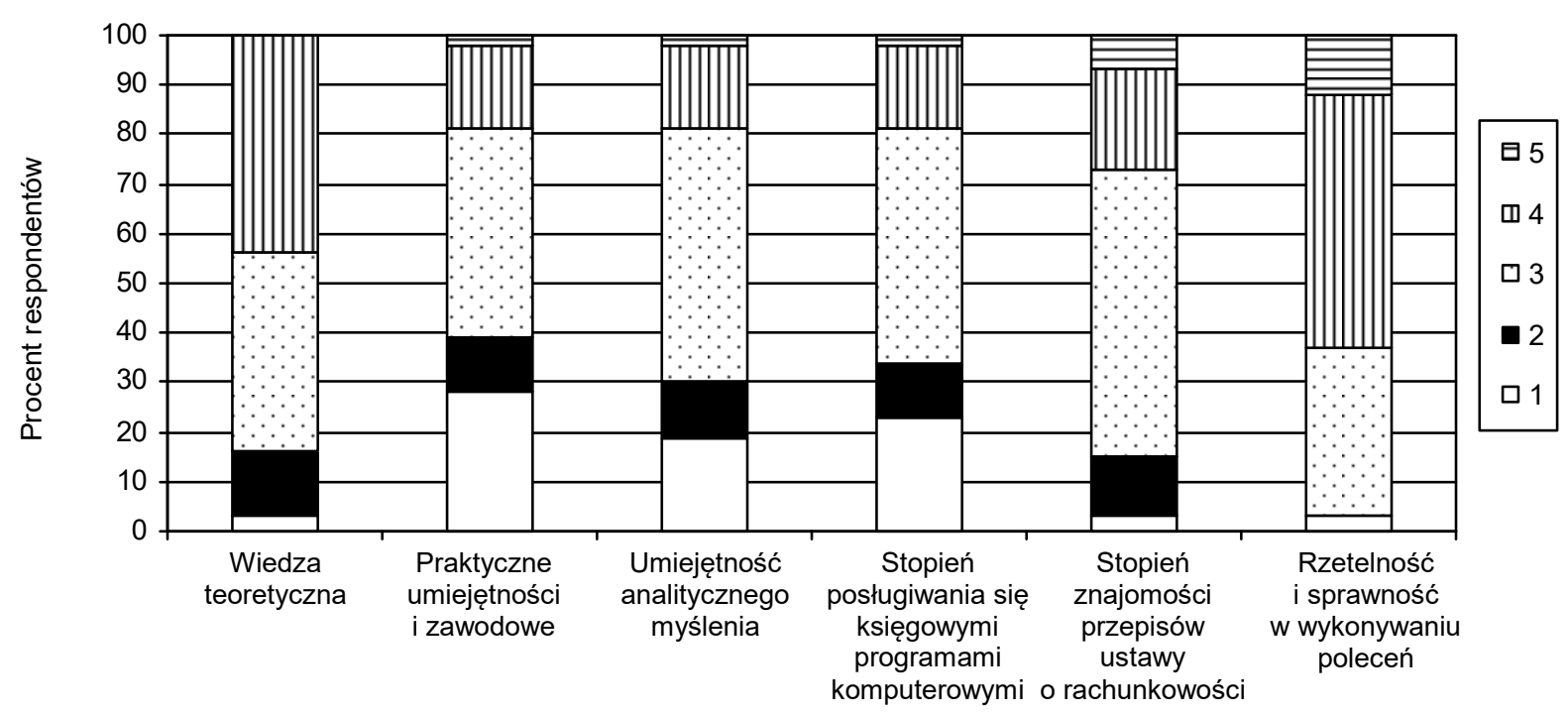

Ryc. 6. Ocena przygotowania absolwentów do podjęcia pracy w biurze rachunkowym Źródło: wyniki badań ankietowych.

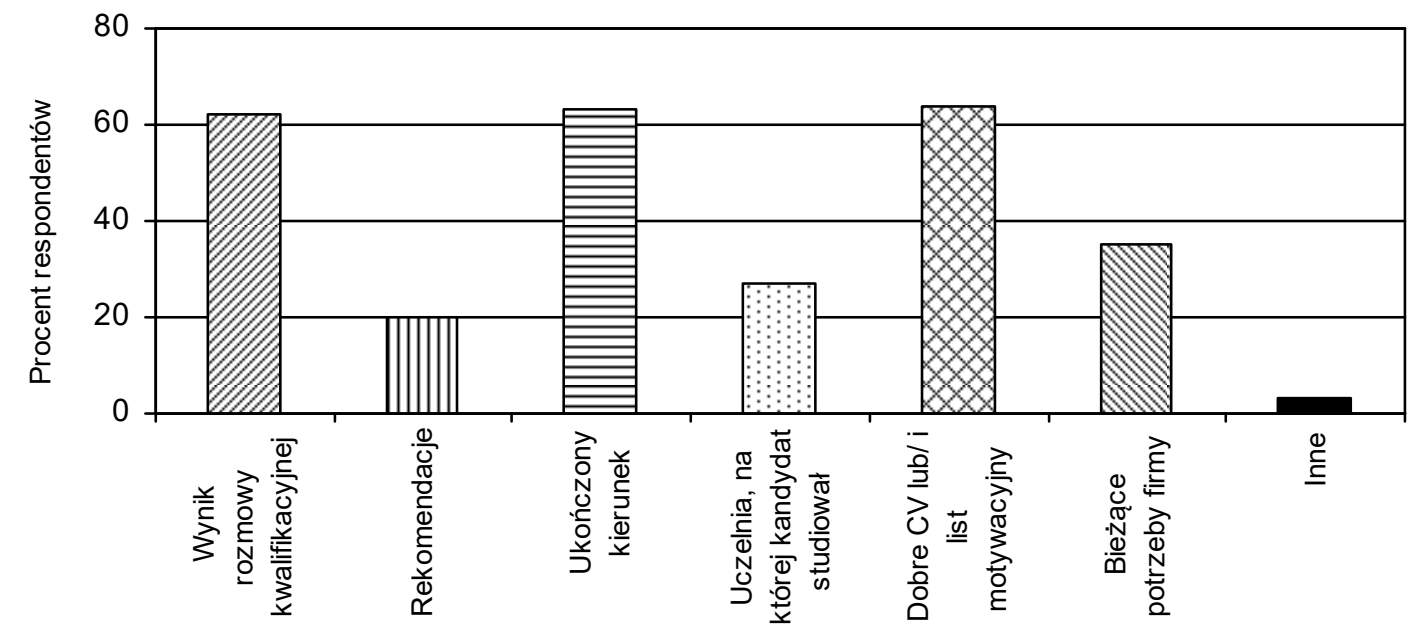

Ryc. 7. Czynniki decydujące o przyjęciu kandydata do pracy Źródło: wyniki badań ankietowych.

Najistotniejszym czynnikiem decydującym o przyjęciu kandydata do pracy według opinii respondentów były wyniki rozmowy kwalifikacyjnej, następnie ukończony kierunek studiów lub specjalność oraz dobre CV i/ lub list motywacyjny. Najmniejsze natomiast znaczenie dla pracodawców mają rekomendacje oraz uczelnia, którą kandydat ukończył.

Celem badania ankietowego przeprowadzonego wśród pracodawców województwa zachodniopomorskiego było także poznanie pożądanych cech i zdolności kandydata potrzebnych do pracy w biurze rachunkowym. Respondenci mogli wskazać więcej niż jedną odpowiedź. Wszystkie spośród wymienionych cech i zdolności okazały się prawie jednakowo ważne. Najważniejsze jednak były umiejętność pracy w zespole, lojalność oraz samodzielność (ryc. 8). 


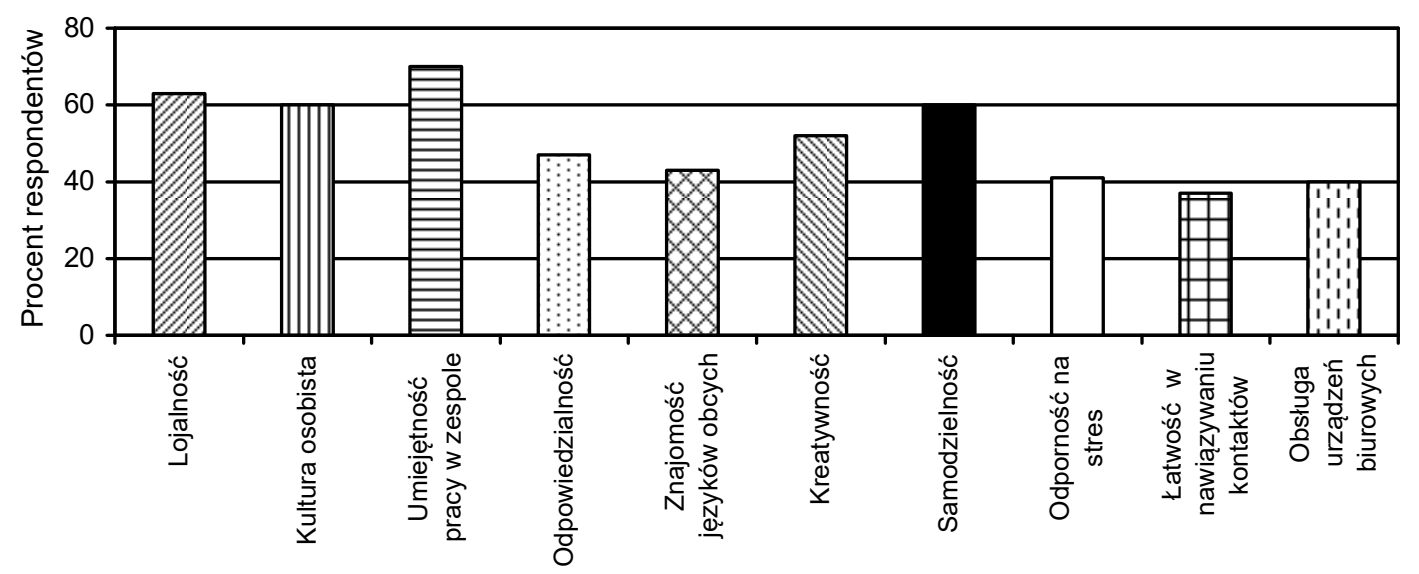

Ryc. 8. Pożądane cechy i zdolności kandydata potrzebne do pracy w biurze rachunkowym Źródło: wyniki badań ankietowych.

$\mathrm{Na}$ pytanie, czy istnieje potrzeba uzupełnienia programów kształcenia w zakresie rachunkowości, ankietowani w $60 \%$ odpowiadali twierdząco. Wszyscy zgodnie stwierdzili, że na studiach ekonomicznych kształcących w zakresie rachunkowości powinno być zdecydowanie więcej zajęć praktycznych. $\mathrm{Na}$ uwagę zasługuje odpowiedź respondenta, który uważa, że w ramach bloków kierunkowych powinny być dokładnie i szczegółowo omówione zasady działania przedsiębiorstwa i stanowisk księgowych; praktyki zawodowe powinny trwać minimum 3 miesiące oraz powinny być zakończone egzaminem przeprowadzonym przez pracodawcę. Zdecydowana większość ankietowanych uważa, że praktyka zawodowa na studiach nie jest wystarczająca do zapoznania studentów z pracą księgowego. Odpowiedź taką udzieliło aż 73,33\% badanych.

Podsumowując wyniki badań ankietowych, zdaniem pracodawców absolwentom studiów ekonomicznych brakuje, przede wszystkim, umiejętności praktycznych, mimo że wiedza teoretyczna jest oceniania bardzo wysoko (Rydzewska i in. 2013). Aby zwiększyć ich szanse na rynku pracy, uczelnie powinny dostosowywać programy kształcenia do zapotrzebowania rynku pracy. Na obecnym etapie zmiany powinny dotyczyć formy prowadzenia zajęć (z podającej na praktyczną) oraz ich liczby godzin, która powinna ulec zwiększeniu. Ponadto praktyki studenckie powinny trwać zdecydowanie dłużej niż obecnie.

\section{PODSUMOWANIE}

Profesjonalnych księgowych zalicza się do grupy zawodów zaufania publicznego. Bez specjalistycznego wsparcia wykwalifikowanych księgowych zarządzającym przedsiębiorstwami trudno podejmować racjonalne decyzje gospodarcze. Wynika to ze skomplikowanego procesu rejestracji zdarzeń gospodarczych i przygotowywania informacji finansowych dla odbiorców wewnętrznych i zewnętrznych. Ponadto dynamiczne zmiany spowodowane globalizacją i standaryzacją przepisów w dziedzinie rachunkowości powodują, iż wymagania wobec tej grupy zawodowej nieustannie rosną. Tym samym powinni oni posiadać szeroką wiedzę oraz umiejętności praktyczne (Drumlak 2013). 
Spełnienie oczekiwań w tym zakresie wymaga, między innymi, innego podejścia do programów nauczania na poziomie szkolnictwa wyższego. Powinny one uwzględniać zdecydowanie większą liczbę godzin zajęć praktycznych. Zwiększenie tej liczby według ankietowanych mogłoby odbyć się kosztem przedmiotów objętych programem studiów, jednakże niezwiązanych $z$ obranym kierunkiem czy specjalnością. Ponadto istotnym elementem praktycznej nauki księgowości mogłyby być praktyki zawodowe realizowane w toku studiów w okresie minimum trzech miesięcy.

Według badanych wiedza i umiejętności zdobyte podczas dostosowanych do oczekiwań studentów i pracodawców zajęć mogą zwiększyć szanse absolwentów wyższych szkół ekonomicznych w znalezieniu odpowiedniej pracy, a tym samym wpłynąć na rozwój ich kariery zawodowej.

\section{PIŚMIENNICTWO}

Drumlak U. 2013. Badanie opinii na temat przygotowania absolwentów kierunku „Finanse i rachunkowość” do wykonywania zawodu księgowego - fragmenty badań. Zesz. Nauk. USzczec., Finanse, Rynki Finansowe, Ubezpieczenia 61(1), 5-18.

Micherda B. 2011. Współczesne aspekty realizacji kontrolnej funkcji rachunkowości. Warszawa, Difin, 22.

Międzynarodowe Standardy Edukacyjne. 2016. Warszawa, SKwP.

Program kształcenia i program studiów, kierunek ekonomia, studia pierwszego stopnia, profil ogólnoakademicki. 2016. Szczecin, ZUT.

Program studiów WNEiZ, http://www.wneiz.pl/studia/sylabusy/sylabusy_FiR_stacjonarne_I_st_2016_ 2017.pdf, dostęp: 20.06.2018.

Program studiów WZiEU, http://www.wzieu.pl/studia/sylabusy/sylabusy_FiR_stacjonarne_l_st_2016_ 2017.pdf, dostęp: 20.06.2018.

Rydzewska-Włodarczyk M., Majchrzak I., Bielec J. 2013. Oczekiwania pracodawców w zakresie kompetencji zawodowych wobec studentów kierunków ekonomia i zarządzanie. Wyniki badań. Folia Pomer. Univ. Technol. Stetin., Oeconomica 303(72), 171-182.

Szczypa P. 2015. Nauczanie rachunkowości - współczesne uwarunkowania i dylematy. Pr. Nauk. UE Wroc. 388, 167-175.

Szydełko A. 2011. Wpływ wybranych form nauczania rachunkowości na edukację księgowych w Polsce. Pr. Mater. Wydz. Zarz. UGdań. 1/2, 417.

Streszczenie. Celem artykułu jest określenie oczekiwań studentów i pracodawców województwa zachodniopomorskiego w zakresie kompetencji i umiejętności dotyczących rachunkowości na podstawie oferty edukacyjnej szczecińskich uczelni państwowych. Ponadto w artykule podjęto próbę określenia kierunków zmian niezbędnych w nauczaniu rachunkowości dla zapewnienia optymalnego przygotowania absolwentów wyższych szkół ekonomicznych do wymagań rynku pracy. Opracowanie artykułu poprzedziły studia literaturowe oraz badania ankietowe przeprowadzone wśród studentów wydziałów ekonomicznych dwóch szczecińskich uczelni oraz pracodawców województwa zachodniopomorskiego. Ponadto analizie poddano programy kształcenia badanych jednostek w zakresie rachunkowości. Głównymi metodami stosowanymi w artykule są analiza źródeł oraz metoda dedukcji i indukcji. Przeprowadzone badania pozwoliły na jednoznaczne stwierdzenie, iż oferta edukacyjna szczecińskich wydziałów ekonomicznych, choć nieustanie podlega przeobrażeniom i dostosowywaniu do zmieniających się potrzeb studentów i rynku pracy, w dalszym ciągu nie spełnia oczekiwań obu badanych stron. Ankietowani wskazują, iż w procesie kształcenia nabywają zbyt dużo wiedzy teoretycznej, a zbyt mało umiejętności praktycznych. Uważają, że te relacje powinny ulec zmianie. 